Last year, for example, as much as $87,000 \mathrm{kgm}$. of pure gold was extracted, and this exceeded the Canadian production. It also represented an increase of forty per cent over the amount obtained in 1932. More still is expected to be obtained in the present year.

\section{Grassland Research in Australia}

$I_{T}$ is not often that research workers are able to review the whole field of their particular investigation in their own country, but grassland agronomists in Australia are placed in this fortunate position by the appearance of Bulletin No. 14 of the Herbage Publication Series of the Institute of Agricultural Botany ("Grassland Research in Australia", Imperial Bureau of Plant Genetics, Aberystwyth, Great Britain, 3s., February 1934). The bulletin contains a comprehensive survey of Australian research work on pasture management and improvement, the genetics, pests and diseases of grass crops, poisonous plants, the introduction of new species and plant physiology as it relates to grasses. For each research centre, the names of the investigators, the scope of the work, experimental procedure and references to published results are given. Two original papers on "The Technique of Pasture Investigations" by J. Griffiths Davies and H. C. Trumble, and "Botanical Analysis of Irrigated Pasture" by E. S. Beruldsen and $\mathbf{A}$. Morgan are also included in the bulletin.

\section{Physics in National Planning}

IN an article on this subject which Prof. Karl T. Compton, of the Massachusetts Institute of Technology, contributes to the July issue of the Review of Scientific Instruments, he points out that physics has given birth to nearly all those ideas which have led to the understanding and use of the forces of Nature ; that almost every branch of industry has benefited from it, and that the pace at which it is developing at the present time assures us of its increasing power to help in the future. A nation which, by anti-educational policy or by inadequate provision for research, puts itself industrially at the mercy of more progressive nations, is courting economic distress and unemployment for the next generation. He considers that the United States Government, in spending only one half of one per cent of its annual budget on its scientific bureaux, is showing a lamentable lack of vision. He urges re-consideration of the place of science in national planning and policy, and better provision for it in the future.

\section{The U.S. National Research Council}

IN several issues of Science during 1933, articles by various authors have appeared surveying the organisation of, and suggestions for needed changes in, the United States National Research Council. These articles have now been issued in pamphlet form as a partial record of the accomplishments of the National Research Council ("A History of the National Research Council, 1919-1933". Washington, D.C. 1933. 50 cents). A survey of the organisation and activities of the Council is contributed by Dr.
Albert L. Barrows, its assistant secretary. The Council originated in an offer made by the National Academy of Sciences of its services to President Wilson in 1916, when it was seen that the United States would become involved in the War. The Council was finally established as a perpetual body on May 18, 1918. The organisation and activities of the following divisions are described by their respective chairmen: Physical Sciences, Prof. F. K. Richtmeyer; Engineering and Industrial Research, Prof. Dugald C. Jackson, Chemistry and Chemical Technology, Prof. Charles A. Kraus; Geology and Geography, Prof. W. H. Twenhofel ; Medical Sciences, Prof. Stanhope Bayne-Jones; Biology and Agriculture, Prof. Fernandus Payne; Anthropology and Psychology, Prof. A. T. Poffenberger. An account of the Research Information Service is contributed by its director, Dr. Clarence J. West, and the assistant secretary of the Council describes the various divisions of general relations (federal, foreign, States and educational). A list of publications is appended.

\section{History of Medicine Congress}

THIS year's Congress of the German Society of the History of Medicine will form part of the ninety-third Congress of the Society of German Men of Science and Physicians, which will be held at Hanover on September 18-19. The following subjects, among others, will be considered: bone finds in the Alamannic graves, by Prof. Georg Sticker ; racial ideas in India, by R. F. G. Moller; Velasquez and the doctrine of heredity by Prof. Haberling; a contribution to the study of medicinal plants, by Edith Heischkel; Cæsarean section by midwives, by Elsaluise Haberling; Novalis and Romanticism, by Prof. Paul Diepgen; Urso, the last doctor, philosopher and theologian at Salerno, by Dr. Rudolf Creotz; the medical faculty at the University of Tyrnau, by Prof. T. von Gyorgi; the correspondence of Drs. Zimmermann and Espenburg with Kotzebue, by Dr. W. Leibbrand; Kestren, the Frankfort municipal doctor, by Dr. Kallmorgen; national and politica1 tendencies in the congresses for natural science 1822-48, by Dr. Ludwig Englert, and Caspar Friedrich Wolff, by Dr. Julius Schuster. Further information can be obtained from Dr. W. Artelt, Universitatsstrasse $3 \mathrm{~b}$, Berlin, N.W.7.

\section{Sixth International Congress for Scientific Management}

Ax the Sixth International Congress for Scientific Management to be held in July of next year, arrangements have been made for the discussion of many papers giving accounts of management in relation to a variety of problems. These include business forecasting, budgetary control, the inculcation of best methods of management, production control and technique, standardisation, the distribution problems of manufacturers, wholesalers and retailers, selective education and training for high administrative positions. Many international and national problems would be affected by the greater use of scientific method. The management of 
industrial and agricultural undertakings is gradually being based on more precise data and on improved techniques of management independent of the many and specific points on which scientific workers of different kinds-chemists, physicists, geologists and many others-are qualified to advise. Management consists in taking decisions with due regard to the multifarious factors of the organisation either within or without the control of the manager. The Congress is well supported by a large number of professional bodies and by eminent industrialists. H.R.H. the Prince of Wales is the patron; the chairman is Sir George Beharrell. Dr. E. F. Armstrong and Sir Henry Fowler are among the chairmen of committees. The fuller programmes and membership forms will be available from Mr. H. Ward, 21 Tothill Street, London, S.W.1, at the end of October. The papers to be discussed will be printed in six volumes and be available to members before the Congress.

\section{Announcements}

The next meeting of the General Assembly of the International Astronomical Union will take place in Paris on July 10-17, 1935.

ON October 13, Sir E. Hilton Young, the Minister of Health, will open the Stenhouse Williams Memorial Library at the National Institute for Research in Dairying, Shinfield, near Reading. The Library was founded in memory of Dr. Stenhouse Williams, the first director of the Institute, who died on February 2,1932 .

The Sixth International Botanical Congress will be held at Amsterdam on September 2-7, 1935 (see Nature, 132, 780, Nov. 18, 1933). The Congress will be divided into the following sections: (1) Agronomy, (2) Cytology, (3) Genetics, (4) Geobotany, Ecology and Phytogeography, (5) Morphology and Anatomy, (6) Mycology and Bacteriology, (7) Phytopathology, (8) Palæobotany, (9) Plant Physiology, (10) Taxonomy and Nomenclature. The principal topics for discussion have been selected. Further information can be obtained from the Secretary, Dr. M. J. Sirks, Wageningen, Holland.

THE twenty-fifth edition of Messrs. Becker and Co.'s (17-29 Hatton Wall, London, E.C.1) catalogue of chemical apparatus, chemicals and general laboratory equipment has recently been issued. It contains 856 pages, and describes a wide field of apparatus and equipment. Recent advances in chemical apparatus are represented by the increasing number of electrically heated units, and the use of special materials such as silica and monel metal for the construction of apparatus. We also note the lowpressure apparatus, including the Kaye steel mercury diffusion pump; thermoelectric equipment and pyrometers; pyrex apparatus with interchangeable standard ground joints; biological apparatus, including microscopes; and projection apparatus. The catalogue will be useful in any laboratory.

Messrs. Williams aNd Norgate, Ltd., announce that they will shortly issue on behalf of the Herbert
Spencer Trustees a volume by Prof. John Garstang, professor of sociology in the University of Liverpool, on "The Kingdom of Solomon" as one of the volumes of the Descriptive Sociology Series.

A comprehensive treatise on the principles and practice of the production and refining of mineral oils entitled "The Science of Petroleum" is in preparation for publication by the Oxford University Press. The British editors are Dr. A. E. Dunstan, chief chemist of the Anglo Persian Oil Company, Prof. A. W. Nash, Department of Oil Engineering, University of Birmingham ; and Mr. H. T. Tizard, rector of the Imperial College of Science. The chief editor in America is Dr. B. T. Brooks. The work will contain articles by nearly three hundred authorities from all parts of the world; every aspect of the science of petroleum is being discussed in articles which, it is hoped, will be authoritative and definitive.

Applicatrons are invited for the following appointments, on or before the dates mentioned : A technical officer in the Admiralty Technical Pool chiefly for work in connexion with small precision mechanical and electrical apparatus-Secretary of the Admiralty (C.E. Branch), Whitehall, London, S.W.1 (Sept. 4). A teacher (evening) of heat engines and hydraulics at the Central Polytechnic, Scarbrook Road, Croydon-Principal (Sept. 10). An assistant curator in the Royal Albert Memorial Museum, Exeter-Town Clerk, endorsed "Assistant Curator" (Sept. 12). A chief inspector of aircraft in the Civil Aviation Directorate of the Government of IndiaHigh Commissioner for India, General Department, India House, Aldwych, London, W.C.2 (Sept. 12). An assistant at the Fuel Research Station, East Greenwich, for work on the preparation of reports and abstracting of technical papers in connexion with the Fuel Research Coal Survey-Establishment Officer, Department of Scientific and Industrial Research, 16 Old Queen Street, Westminster, S.W.1 (Sept. 15). Assistant civil engineers in the Civil Engineer-in-Chief's Department, Admiralty-Civil Engineer-in-Chief (Sept. 15). A junior technical examiner (male), formerly known as draughtsman, in the Lands Branch of the War DepartmentSecretary, Civil Service Commission, Burlington Gardens, London, W.1 (Sept. 20). An engineering chemist, Public Works Department, Gold CoastDirector of Recruitment (Colonial Service), 2 Richmond Terrace, London, S.W.1 (Sept. 30). A professor of pure mathematics in the University of Sydney, Australia, particulars obtainable from the Universities Bureau of the British Empire, 88A Gower Street, London, W.C.1--Registrar, University of Sydney (Oct. 15). An assistant (Grade III) for work on general aircraft instrument design and test in the Directorate of Technical Development, Air Ministry-Chief Superintendent, Royal Aircraft Establishment, South Farmborough, Hants (quoting reference No. A.617). A laboratory assistant (male) at the War Department's Experimental Station, Porton-Commandant, Experimental Station, Porton, near Salisbury. 